\title{
Repair and Strengthening of Timber Floors of Pančevo Diocese by Timber-Concrete Coupling Technique
}

\author{
Radovan CVETKOVIĆ, Dragoslav STOJIĆ, Nemanja MARKOVIĆ, Marina TRAJKOVIĆ, Darko ŽIVKOVIĆ
}

\begin{abstract}
The building of Diocese is located in the very center of Pančevo, at the very corner of the City Park. The object is of a great historic and cultural importance and it has been already in use for two centuries. The object was built in the masonry system, using stones and bricks for the walls, and timber for the floor and roof structure. This paper gives the description of repair and reconstruction of timber floors of $6,5 \mathrm{~m}$, by coupling timber and concrete technique. The detailed design concept is shown, based on the theory of coupling elasticity and the concepts of ultimate and serviceability limit state of timber structures (Eurocode 5). For the accepted design model, its numerical verification was carried out by the proper simulation in software ABAQUS 6.11. For timber, concrete and adopted fasteners for their coupling, certain laws of material behaving were adopted, as well as their evaluated and proved mechanical characteristics. All this was done to carry out design procedure. The obtained comparative results were presented, from the aspect of nonlinear stress strain analysis in characteristic sections and zones of applied design model. Finally, a short review of reconstruction based on the previous theoretical-analytical observations was given.
\end{abstract}

Keywords: coupling timber and concrete; diocese; numerical simulation; repair; strengthening; timber floors

\section{INTRODUCTION}

The Diocese located in the center of Pančevo, on the edge of City Park is of a great historical and cultural significance (Fig. 1 and 2). History of past period is embedded in all joints of its walls. Historical documents mention its existence since the beginning of the nineteenth century. In previous times, it suffered a variety of rehabilitation, reconstruction, repurposing, caused by bad, good or unconscious intentions of people, historical trends and the impact of weather conditions.

Now, the structure of the Diocese is in a state that, thanks to brilliance and splendor of the facade, to the ordinary passers-by, looks inscrutable and completely marginal. Unfortunately, a walk through the hallways, stairs, numerous rooms and attic, to professionals gives alarming signals.

This paper represents theoretical and practical observations related to the structural condition of timber floors and taken steps for their strengthening, necessary for the modern use of the building [1]. Regarding the observations and determining the state of structure and reconstruction [2, 3], of the Diocese, for repair of timber floors the process of coupling beams with reinforced concrete of the thickness $d=6-8 \mathrm{~cm}$, by head screws was suggested. The screws, length $l=140 \mathrm{~mm}$ and diameter $d$ $=10 \mathrm{~mm}$, were built in at a certain distance, along the timber beam, according to details shown in Fig. 4 .

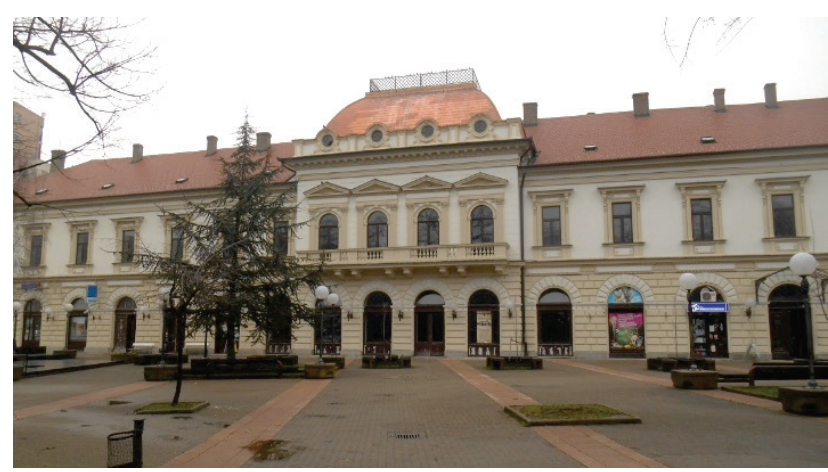

Figure 1 The Diocese in Pančevo- frontal view

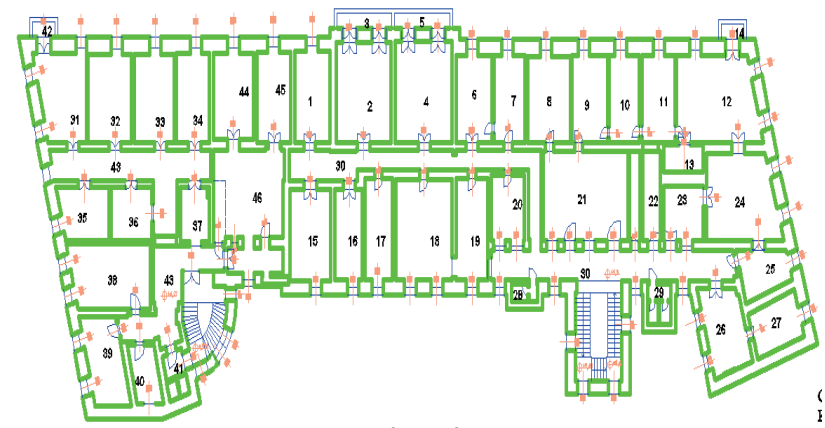

Figure 2 The ground floor of Diocese in Pančevo

Design was carried out by current procedures based on hypotheses of the theory of elasticity and design concept of ultimate (ULS) and serviceability limit state (SLS) of structures (EC 2, EC 4, EC 5) [4, 5]. By analytical procedure and suitable numerical simulation the stressdeformation state and state of design strengths of both materials were proved satisfactory, and the distance between screws in relation to design loading accepted. In the following chapter theoretical basics of timber-concrete coupling have been given.

\section{THE BASE OF THEORY OF ELASTIC COMPOUND}

Analysis of composite timber-concrete beam demands knowledge of relationship between stress and deformations for all three components, timber, concrete and connecting system.

Complexity of the problem is composed of determining this relationship and introducing a large number of parameters, which complicates calculations.

For practical calculations, we can make certain simplifications, certain assumptions that enable us to reach the solution relatively easily. The approximate calculation method for semi-rigid structures is more appropriate to use in engineering, because the design procedure is simpler. The displacement between mechanically connected timber and concrete is taken into account in structural models by means of the slip modulus [6].

The basic assumptions of composite timber-concrete structures are the following $[7,8]$ : 
- displacements owing to bending are small and, therefore, the theory of small displacements is valid,

displacements owing to shear deformations are negligible in each element,

- Bernoulli-Navier's hypothesis about plane sections is not valid along the whole cross-section, but it is individually valid both for timber cross-section and concrete crosssection,

- timber and concrete are isotropic elastic materials and Hooke's law is valid,

- load-slip relationship for the connector can be approximated to elastic-linear. Connectors are placed at certain distance and can be regarded as equivalent continuous connection.

The design of the composite beams is regulated in the appendix B of the Eurocode 5. The stress calculation for timber and concrete and the calculation of the connectors is to be performed in accordance with the theory of the elastic compound $[9,10]$.

According to recommendations from the appendix B of the Eurocode 5, for cross-section shown by Fig.3, geometrical properties, stresses, and characteristics of connection can be calculated according to the next procedure:

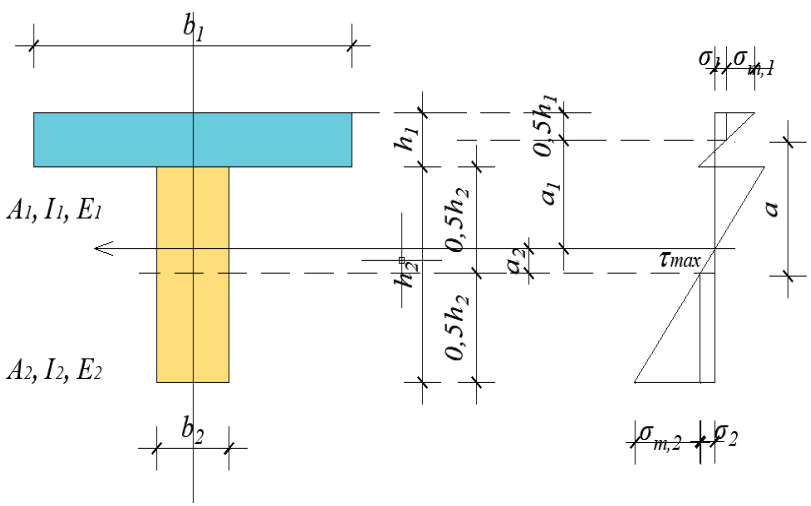

Figure 3 Geometrical properties and stress distribution

The stress in the centre of gravity of the timber and concrete part of cross-section can be calculated according to expressions:

$$
\begin{gathered}
\sigma_{1}=\frac{\gamma_{1} E_{1} a_{1} M}{(E I)_{\mathrm{eff}}}, \\
\sigma_{2}=\frac{\gamma_{1} E_{2} a_{2} M}{(E I)_{\mathrm{eff}}} .
\end{gathered}
$$

The effective bending stiffness will be calculated as the following:

$$
(E I)_{\mathrm{eff}}=\sum_{i=1}^{n}\left(E_{i} I_{i}+\gamma_{i} E_{i} A_{i} a_{i}^{2}\right)
$$

where $i$ is number of elements of composite cross-section. In case of T-cross section, $i=2 . E$ is the average value of modulus of elasticity for concrete and timber, respectively,

$$
A_{i}=b_{i} h_{i},
$$

$I_{i}=\frac{b_{i} h_{i}^{3}}{12}$

$\gamma_{2}=1$

$\gamma_{i}=\left[1+\pi^{2} E_{i} A_{i} s_{i} /\left(K_{i} \ell^{2}\right)\right]^{-1}$, for $i=1$ and $i=3$,

$a_{2}=\frac{\gamma_{1} E_{1} A_{1}\left(h_{1}+h_{2}\right)-\gamma_{3} E_{3} A_{3}\left(h_{2}+h_{3}\right)}{2 \sum_{i=1}^{3} \gamma_{i} E_{i} A_{i}}$.

For T-cross sections, $h_{3}=0$.

The normal stresses are given by equations:

$$
\begin{gathered}
\sigma_{i}=\frac{\gamma_{i} E_{i} a_{i} M}{(E I)_{\mathrm{eff}}} \\
\sigma_{m, i}=\frac{0,5 E_{i} h_{i} M}{(E I)_{\mathrm{eff}}} .
\end{gathered}
$$

The shear stress has the maximum magnitude at the point where normal stresses are equal to zero. Maximum shear stress at certain point of cross-section of timber element should be calculated according to expression:

$\tau_{2, \max }=\frac{\left(\gamma_{3} E_{3} A_{3} a_{3}+0,5 E_{2} b_{2} h^{2}\right) V}{b_{2}(E I)_{\mathrm{eff}}}$.

Load of the fastener should be calculated according to expression:

$F_{i}=\frac{\gamma_{i} E_{i} A_{i} a_{i} s_{i} V}{(E I)_{\mathrm{eff}}}$

with $i=1$ and 3 , where $s_{i}=s_{i}(x)$ is distance between fasteners determined in $\mathrm{B} 1.3$ and $V=V(x)$.

In the equations given above, the signs have the following meanings: $M$ is bending moment, $J_{i}$, design moment of inertia, $a_{1}, a_{2}$ are distances between centroids of both, timber and concrete parts, from centroid of whole cross-section, $h_{1}, h_{2}$ are heights of both, timber and concrete part, respectively, $\gamma$ is slip modulus of connecting system and $E_{1}, E_{2}$ are modulus of elasticity of both, concrete and timber, respectively.

\section{DESIGN OF COMPOSITE TIMBER-CONCRETE FLOOR ACCORDING TO EUROCODE 5}

Thus, on the basis of everything written above, for adopted composite timber- concrete floor structure, proper stress-strain analysis can be applied.

Design analysis was carried out in accordance with the theory of elastic coupling and the procedure defined in Annex B, Eurocode 5. The real geometrical characteristics of coupled cross-section of the separated representative segment of width $1 \mathrm{~m}$, are shown in Fig. 4 . The real model is the subject of numerical simulation in software ABAQUS 6.11.

In Fig. 5, the approximate model of cross-section of the representative segment of coupled timber-concrete floor structure is presented. 

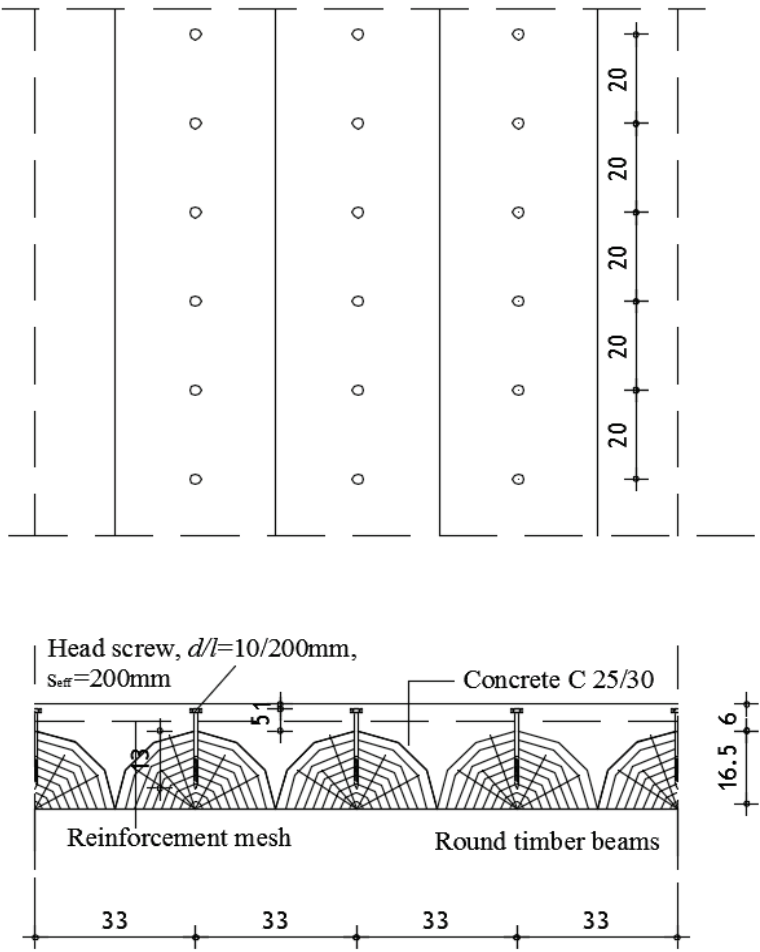

Figure 4 Geometrical properties of the real representative composite crosssection, numerically modelled in ABAQUS

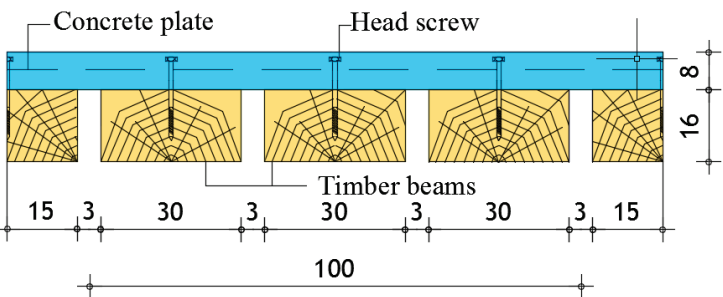

Figure $\mathbf{5}$ Geometrical properties of the composite cross-section, approximate design model

In Fig. 6, geometrical characteristics of sub-segment of approximate representative segment, are given and for such design model analytical stress-strain process was carried out in accordance with Annex B of Eurocode 5.

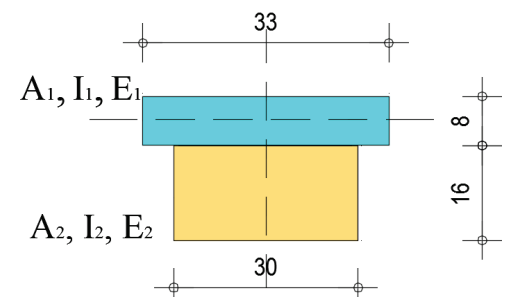

Figure 6 Geometrical properties of cross-section of composite sub-segment of the approximate design model for the analytical observation

Furthermore, the design procedure based on values of mechanical characteristics of material and certain parameters taken from EN standards is given. The used concrete, according to testing and attestation, was put in C25/30. Rounded timber beams, almost two-century old, made from Carpathian pine, are in good state.

Serviceability conditions of timber floors in this object were very beneficial. Floor coverings were protecting round timber beams from insects, humidity, microorganisms. Unfortunately, we were not capable of proceeding serious testing according to relevant standards and determining mechanical characteristics of rounded timber. Strength class C 24 and service class 2 were adopted and we think that the value was underestimated.

\subsection{Mechanical Properties of Timber, Concrete and Connecting System - Adopted Values}

Design values of mechanical characteristics of elements of composite cross-section according to EC 2, EC 4 and EC 5 are given in Tab. 1 and Tab. 2. Design values of mechanical characteristics of timber were determined by characteristic values given in the standard EN 338 and partial safety factors for materials. Service class of timber, proper value of strength modification factor $k_{\bmod }=0,8$ (ULS) and deformation factor $k_{\mathrm{def}}=0,6$ (SLS) were taken into consideration. Values of these factors depend on service class of timber and duration of load.

Table 1 Concrete strength class C25/30 (ENV 206)

\begin{tabular}{|l|c|}
\hline Design compression strength & $f_{\mathrm{cd}}=11,76 \mathrm{MPa}$ \\
\hline Design tension strength & $f_{\mathrm{ctmd}}=1,47 \mathrm{MPa}$ \\
\hline Mean modulus of elasticity & $E_{1}=E_{\mathrm{cm}}=30500 \mathrm{MPa}$ \\
\hline
\end{tabular}

Table 2 Solid timber strength class C24 (SRBS EN 338)

\begin{tabular}{|l|c|}
\hline Design bending strength & $f_{\mathrm{m}, \mathrm{d}}=11,76 \mathrm{MPa}$ \\
\hline $\begin{array}{l}\text { Design compression strength parallel } \\
\text { to the grain }\end{array}$ & $f_{\mathrm{c}, 0, \mathrm{~d}}=12,92 \mathrm{MPa}$ \\
\hline $\begin{array}{l}\text { Design tension strength parallel to } \\
\text { the grain }\end{array}$ & $f_{\mathrm{t}, 0, \mathrm{~d}}=8,61 \mathrm{MPa}$ \\
\hline $\begin{array}{l}\text { Design compression strength } \\
\text { perpendicular to the grain }\end{array}$ & $f_{\mathrm{c}, 90, \mathrm{~d}}=1,54 \mathrm{MPa}$ \\
\hline Design shear strength & $f_{\mathrm{v}, \mathrm{d}}=2,46 \mathrm{MPa}$ \\
\hline $\begin{array}{l}\text { Mean modulus of elasticity } \\
\text { parallel to the grain }\end{array}$ & $E_{0, \text { mean }}=11000 \mathrm{MPa}$ \\
\hline $\begin{array}{l}\text { The } 5^{\text {th }} \text { percentile modulus of } \\
\text { elasticity parallel to the grain }\end{array}$ & $E_{0,05}=7400 \mathrm{MPa}$ \\
\hline Mean shear modulus & $G_{\text {mean }}=690 \mathrm{MPa}$ \\
\hline Characteristic density & $\rho_{\mathrm{k}}=420 \mathrm{~kg} / \mathrm{m}^{3}$ \\
\hline
\end{tabular}

\subsubsection{Determining the Value of Slip Modulus of Head Screw}

Because of the lack of experimental data and data precisely defined by regulation regarding mechanical properties of head screw built in two-century-old pine timber, the approximate values defined by Eurocode 5 (EC 5 ) are considered in the calculation.

As a connecting system, head screw (EN 10080), $d=$ $10 \mathrm{~mm}$, is used.

Effective distance of the head screw along the connecting surface between timber and concrete can be calculated as:

$s_{\text {eff }}=0,75 s_{\text {min }}+0,25 s_{\text {max }}=20 \mathrm{~cm}=200 \mathrm{~mm}$

Slip modulus according to EC 5:

$K_{\mathrm{ser}}=\frac{2 \cdot \rho_{\mathrm{k}}^{1,5} d}{23}=7845 \mathrm{~N} / \mathrm{mm}$

$K_{\mathrm{u}}=\frac{2}{3} \cdot K_{\mathrm{ser}}=4990 \mathrm{~N} / \mathrm{mm}$. 


\subsubsection{Load Bearing Capacity of the Connecting System}

Load bearing capacity of the connecting system, in this case of head screw, $d=10 \mathrm{~mm}$, can be calculated from different conditions taking into account relation between concrete and screw, timber and screw, separately [11].

Thus, load bearing capacity of the head screw regarding concrete:

$R_{\mathrm{d}}=0,29 \alpha d^{2} \sqrt{\frac{f_{\mathrm{ck}} E_{\mathrm{cm}}}{\gamma_{\mathrm{v}}}}=R_{\mathrm{d} 1}$

where $d$ is diameter, $f_{\mathrm{ck}}$ is characteristic compression strength of the concrete cube, $\gamma_{\mathrm{v}}$ is partial material safety factor $\left(\gamma_{\mathrm{v}}=1,25\right)$ and $E_{\mathrm{cm}}$ is mean value modulus elasticity of concrete.

The shear capacity of the head screw is defined by the following equation (EN 14555):

$R_{\mathrm{d}}=\frac{0,8 f_{\mathrm{u}} \pi d^{2}}{4 \gamma_{\mathrm{v}}}=R_{\mathrm{d} 2}$

Load bearing capacity of the head screw regarding timber can be calculated by equations:

$$
\begin{aligned}
& R_{\mathrm{d}}=2,3 \sqrt{M_{\mathrm{y}, \mathrm{d}} \cdot f_{\mathrm{h}, 2, \mathrm{~d}} \cdot d}=R_{\mathrm{d} 3} \\
& M_{\mathrm{y}, \mathrm{d}}=\frac{0,3 \cdot f_{\mathrm{u}, \mathrm{k}} \cdot d^{2,6}}{\gamma_{\mathrm{m}}} \\
& f_{\mathrm{h}, 2, \mathrm{~d}}=\frac{0,082(1-0,01 d) \rho_{\mathrm{k}} \cdot k_{\mathrm{mod}}}{\gamma_{\mathrm{m}}}
\end{aligned}
$$

where $M_{\mathrm{y}, \mathrm{d}}$ is design yield moment value, $f_{\mathrm{u}, \mathrm{k}}=500 \mathrm{MPa}$ and $f_{\mathrm{h}, 2, \mathrm{~d}}$ is design embedment strength of timber.

In Tab. 3 the results according to conditions and procedure described by the expressions given above are presented.

Table 3 The design values of load bearing capacity of the head screw

\begin{tabular}{|c|c|}
\hline$R_{\mathrm{d} 1}$ & $22,65 \mathrm{kN}$ \\
\hline$R_{\mathrm{d} 2}$ & $25,12 \mathrm{kN}$ \\
\hline$R_{\mathrm{d} 3}$ & $9,89 \mathrm{kN}$ \\
\hline
\end{tabular}

Final load bearing capacity of the head screw, as a connecting system, is $R_{\mathrm{d}}=R_{\mathrm{d} 3}=9,89 \mathrm{kN}$.

\subsubsection{The Values of Internal Forces}

The design load case is the result of combination of self-weight of the composite floor plus the uniform variable load. Estimated permanent load is $3,0 \mathrm{kN} / \mathrm{m}^{2}$. Variable load, estimated as medium-term load (mediumterm-load duration class) is $2,0 \mathrm{kN} / \mathrm{m}^{2}$. Using partial safety factors of loads $(1,35 ; 1,50)$ we obtained the value of limit load, $g=7,05 \mathrm{kN} / \mathrm{m}^{2}$. Design value of bending moment at mid span is equal to $M_{\mathrm{d}}=12,41 \mathrm{kN} \cdot \mathrm{m}$ and designvalue of shear force is equal to $V_{\mathrm{d}}=7,63 \mathrm{kN}$.

\subsection{Design According to Ultimate Limit State (ULS)}

Design of a composite timber-concrete floor structure, according to ultimate limit state [12], is based on geometrical and mechanical properties of cross-section shown in Fig. 6. These parameters are given in Tab. 4.

Table 4 Geometrical and mechanical properties of cross-section (ULS design)

\begin{tabular}{|c|c|}
\hline$A_{1}=28000 \mathrm{~mm}^{2}$ & $A_{2}=48000 \mathrm{~mm}^{2}$ \\
\hline$I_{1}=149333333,33 \mathrm{~mm}^{4}$ & $I_{2}=102400000 \mathrm{~mm}^{4}$ \\
\hline$E_{1}=E_{\mathrm{cm}}=30500 \mathrm{MPa}$ & $E_{2}=E_{0,05}=7400 \mathrm{MPa}$ \\
\hline \multicolumn{2}{|c|}{$K_{\mathrm{u}}=4990 \mathrm{~N} / \mathrm{mm}$} \\
\hline
\end{tabular}

The values of the parameters required for the assessment of the stress state in timber and concrete part of composite cross-section, as well as the capacity of head screw determined by expressions given in Chapter 2, are presented in Tab. 5.

Table 5 The values of parameters required for the stress state design

\begin{tabular}{|c|c|}
\hline$\gamma_{1}$ & 0,11 \\
\hline$a_{1}$ & $82,57 \mathrm{~mm}$ \\
\hline$a_{2}$ & $37,43 \mathrm{~mm}$ \\
\hline$(E I)_{\mathrm{eff}}$ & $2,3513 \times 10^{12} \mathrm{~N} \cdot \mathrm{mm}^{2}$ \\
\hline
\end{tabular}

Design values of normal stresses in the concrete part of the composite cross-section:

$$
\begin{aligned}
\sigma_{\mathrm{c}, 1, \mathrm{~d}} & =\frac{\gamma_{1} E_{1} a_{1} M_{\mathrm{d}}}{(E I)_{\mathrm{eff}}}=1,46 \mathrm{MPa} \\
\sigma_{\mathrm{m}, 1, \mathrm{~d}} & =\frac{0,5 E_{1} h_{1} M_{\mathrm{d}}}{(E I)_{\mathrm{eff}}}=6,44 \mathrm{MPa}
\end{aligned}
$$

Total stress state in upper and lower fibre of the concrete part of the composite cross-section, respectively:

$$
\begin{aligned}
& \sigma_{\mathrm{c}, \mathrm{d}}=\sigma_{\mathrm{c}, 1, \mathrm{~d}}+\sigma_{\mathrm{m}, 1, \mathrm{~d}}=7,90 \mathrm{MPa} \leq f_{\mathrm{cd}}=11,76 \mathrm{MPa} \\
& \sigma_{\mathrm{c}, \mathrm{t}, \mathrm{d}}=\sigma_{\mathrm{m}, 1, \mathrm{~d}}-\sigma_{\mathrm{c}, 1, \mathrm{~d}}=4,96 \mathrm{MPa}>f_{\mathrm{ctmd}}=1,47 \mathrm{MPa}
\end{aligned}
$$

The stress state in the timber part of the cross-section:

$$
\begin{aligned}
& \sigma_{\mathrm{t}, 2, \mathrm{~d}}=\frac{\gamma_{2} E_{2} a_{2} M_{\mathrm{d}}}{(E I)_{\mathrm{eff}}}=1,462 \mathrm{MPa} \\
& \sigma_{\mathrm{m}, 2, \mathrm{~d}}=\frac{0,5 E_{2} h_{2} M_{\mathrm{d}}}{(E I)_{\mathrm{eff}}}=3,12 \mathrm{MPa} \\
& \frac{\sigma_{\mathrm{t}, 2, \mathrm{~d}}}{f_{\mathrm{t}, 0, \mathrm{~d}}}+\frac{\sigma_{\mathrm{m}, 2, \mathrm{~d}}}{f_{\mathrm{m}, \mathrm{d}}}=\frac{1,462}{8,61}+\frac{3,12}{14,76} \leq 1,0 .
\end{aligned}
$$

Design shear stress at certain point along the height of timber element of the composite cross-section:

$$
\tau_{2, \max }=\frac{0,5 E_{2} h_{2}^{2} V_{\mathrm{d}}}{(E I)_{\mathrm{eff}}}=0,31 \leq f_{\mathrm{v}, \mathrm{d}}=2,46 \mathrm{MPa}
$$

Loading of head screw:

$$
F_{1, \mathrm{~d}}=\frac{\gamma_{1} E_{1} A_{1} a_{1} s_{\min } V_{\mathrm{d}}}{(E I)_{\mathrm{eff}}}=5,03 \mathrm{kN}<R_{\mathrm{d} 3}=9,89 \mathrm{kN}
$$




\subsection{Design According to Serviceability Limit State (SLS)}

Design of deflection at a mid span of a composite timber-concrete floor structure is based on geometrical and mechanical properties of cross-section shown in Fig. 6. These parameters are given in Tab. 6.

Table 6 Geometrical and mechanical properties of cross-section (ULS design)

\begin{tabular}{|c|c|}
\hline$A_{1}=28000 \mathrm{~mm}^{2}$ & $A_{2}=48000 \mathrm{~mm}^{2}$ \\
\hline$I_{1}=149333333,33 \mathrm{~mm}^{4}$ & $I_{2}=102400000 \mathrm{~mm}^{4}$ \\
\hline$E_{1}=E_{\mathrm{cm}}=30500 \mathrm{MPa}$ & $E_{2}=E_{\text {mean }}=11000 \mathrm{MPa}$ \\
\hline \multicolumn{2}{|c|}{$K_{\text {ser }}=7845 \mathrm{~N} / \mathrm{mm}$} \\
\hline
\end{tabular}

The values of the parameters required for the design of the total deflection are presented in Tab. 7.

Table 7 The values of the parameters required for the design of deflection

\begin{tabular}{|c|c|}
\hline$\gamma_{1}$ & 0,16 \\
\hline$a_{1}$ & $95,33 \mathrm{~mm}$ \\
\hline$a_{2}$ & $24,67 \mathrm{~mm}$ \\
\hline$(E I)_{\text {eff }}$ & $3,145 \times 10^{12} \mathrm{~N} \cdot \mathrm{mm}^{2}$ \\
\hline
\end{tabular}

The value of final elastic deflection:

$$
u_{1, \text { fin }}=\frac{5}{384} \cdot \frac{q_{\mathrm{k}}\left(1+k_{\mathrm{def}}\right) \cdot \ell^{4}}{(E I)_{\mathrm{eff}}}=19,70 \mathrm{~mm} \leq \frac{6500}{200}=32,5 \mathrm{~mm}
$$

\section{NUMERICAL SIMULATION OF COMPOSITE TIMBER-CONCRETE FLOOR}

Numerical modeling of structures is a powerful scientific method by which it is possible to simulate many physical processes and influences, which determine their mechanical behaviour during their life-time. In that way it is likely to come to characteristics of some phenomena in behaviour, for a shorter period and less expenses, which is often not characteristic for experimental research. This is highly important to apply in structural analysis or their elements, which need to be tested by real prototypes.

Numerical modelling of strengthened, coupled timberconcrete floor structure was carried out by finite element method (FEM), using software ABAQUS 6.11 [13]. By this process it is possible to verify results obtained by analytical procedure as well as results which can be obtained by eventual testing of composite timber-concrete floor structure on the construction site. By modelling in ABAQUS 6.11 it is possible to use 3D linear analysis of elements of composite floor structure by application of adequate constitutive laws of materials, which are further described in details.

\subsection{The Material Model of Timber - Transversal Orthotropy}

The material model for numerical simulation of timber part of coupled cross-section was adopted as linear elastic transversal orthotropy.

"Engineering constants", $D_{i j k l}$, of material whose orthotropic behaviour is accepted as a model, are based on experimentally obtained or standard accepted values of mechanical parameters of stiffness in proper directions.

Linear-elastic behaviour of timber as transversal orthotropic material can be defined by a proper stiffness matrix, which is composed of 9 independent parameters. For such a model, stress-strain relation is:

$$
\left\{\begin{array}{l}
\sigma_{11} \\
\sigma_{22} \\
\sigma_{33} \\
\sigma_{12} \\
\sigma_{13} \\
\sigma_{23}
\end{array}\right\}=\left[\begin{array}{cccccc}
D_{1111} & D_{1122} & D_{1133} & 0 & 0 & 0 \\
& D_{2222} & D_{2233} & 0 & 0 & 0 \\
& & D_{3333} & 0 & 0 & 0 \\
& & & D_{1212} & 0 & 0 \\
& s y m & & & D_{1313} & \\
& & & & & D_{2323}
\end{array}\right\}
$$$$
\left\{\begin{array}{l}
\varepsilon_{11} \\
\varepsilon_{22} \\
\varepsilon_{33} \\
\gamma_{12} \\
\gamma_{13} \\
\gamma_{23}
\end{array}\right\}=\left[D^{e l}\right]\left\{\begin{array}{l}
\varepsilon_{11} \\
\varepsilon_{22} \\
\varepsilon_{33} \\
\gamma_{12} \\
\gamma_{13} \\
\gamma_{23}
\end{array}\right\} .
$$

Constants are calculated using the following relations and the obtained values are input at the proper step of numerical modelling in ABAQUS 6.11.

$$
\begin{aligned}
& D_{1111}=E_{1}\left(1-v_{23} v_{32}\right) \Upsilon \\
& D_{2222}=E_{2}\left(1-v_{13} v_{31}\right) \Upsilon \\
& D_{3333}=E_{3}\left(1-v_{12} v_{21}\right) \Upsilon \\
& D_{1122}=E_{1}\left(v_{21}+v_{31} v_{23}\right) \Upsilon=E_{2}\left(v_{12}+v_{32} v_{13}\right) \Upsilon \\
& D_{1133}=E_{1}\left(v_{31}+v_{21} v_{32}\right) \Upsilon=E_{3}\left(v_{13}+v_{12} v_{23}\right) \Upsilon \\
& D_{2233}=E_{2}\left(v_{32}+v_{12} v_{31}\right) \Upsilon=E_{3}\left(v_{23}+v_{21} v_{13}\right) \Upsilon \\
& D_{1212}=G_{12} \\
& D_{1313}=G_{13} \\
& D_{2323}=G_{23}
\end{aligned}
$$

Constant $\Upsilon$ can be calculated in the following way:

$$
\Upsilon=\frac{1}{1-v_{12} v_{21}-v_{23} v_{32}-v_{31} v_{13}-2 v_{21} v_{32} v_{13}}
$$

\subsection{Material Models of Concrete and Steel: Linear-Elastic Behaviour}

In numerical model, concrete as material and connecting system (head screw-steel) were treated as isotropic materials and the constitutive laws of behaviour were adopted in linear-elastic field.

The total stress state was defined by well-known relation:

$$
\sigma=D^{e l} \varepsilon^{e l},
$$

where: $\sigma$ is total stress (Cauchy stress in finite-strain problems), $D^{e l}$ is elastic matrix of stiffness in tensor form and $\varepsilon^{e l}$ total elastic strain ( $\log$ strain in finite-strain problems).

It should be noted, because of stability of solution, that this material model should not be used if large elastic strains are to be expected. In such a case, for modelling isotropic characteristics of concrete and steel in the area of elastic behaviour, the hyper-elastic material model should be used. 


\subsection{Modelling the Connection between Concrete, Timber and Head Screw by "Embedded Element" Technique}

"Embedded element" technique is used for modelling the connection of head screw (connecting system), which is with one part in concrete plate and with the other one in rounded timber beam. During modelling attention should be paid to geometrical relation of nodes of finite elements (FE) of embedded head screw and nodes of FE of a rounded timber beam and concrete plate, that is elements which are "host" in relation to an element which is to be embedded.

Different types of elements can be used in this technique: two-dimensional models, three-dimensional models, axi-symmetric models. However, the number of degrees of freedom (DOF) considering displacements in nodes of embedded element must be equal to the number of DOF of "host" element.

\subsection{Numerical Modelling - Results}

Regarding applied constitutive laws of materials and mechanical and geometrical characteristics of elements of newly-projected timber-concrete floor structure, the geometry of model and loading distribution, which completely match the Diocese's real behaviour, were formed. The characteristic separated part of composite timber-concrete floor structure, of the unit width and span of $6,5 \mathrm{~m}$, whose geometrical characteristics are shown in Fig. 4, has been modeled in software ABAQUS 6.11. Head screws were modelled as separated elements and were treated as "beam" elements.

Material constants and physical parameters, used in modelling in ABAQUS and in accordance with adopted constitutive laws of materials, are shown in Tab. 8 .

\begin{tabular}{|c|c|c|c|}
\hline & Timber & Concrete & Steel \\
\hline \multicolumn{4}{|c|}{ Modulus of elasticity, $E(\mathrm{MPa})$} \\
\hline$E_{1}$ & 11000 & 30000 & 210000 \\
\hline$E_{2}$ & 370 & 30000 & 210000 \\
\hline$E_{3}$ & 370 & 30000 & 210000 \\
\hline \multicolumn{4}{|c|}{ Poisson's coefficientsv } \\
\hline$v_{12}$ & 0,4 & 0,2 & 0,3 \\
\hline$v_{13}$ & 0,4 & 0,2 & 0,3 \\
\hline$v_{23}$ & 0,4 & 0,2 & 0,3 \\
\hline$v_{12}$ & 0,4 & 0,2 & 0,3 \\
\hline \multicolumn{4}{|c|}{ Shear modulus $G(\mathrm{MPa})$} \\
\hline$G_{12}$ & 132,14 & 12500 & 79300 \\
\hline$G_{13}$ & 715 & 12500 & 79300 \\
\hline$G_{23}$ & 715 & 12500 & 79300 \\
\hline \multicolumn{4}{|c|}{ "Engineering constants" } \\
\hline$D_{1111}$ & 1016,4 & - & - \\
\hline$D_{1122}$ & 247,83 & - & - \\
\hline$D_{2222}$ & 445,37 & - & - \\
\hline$D_{1133}$ & 247,83 & - & - \\
\hline$D_{2233}$ & 176,75 & - & - \\
\hline$D_{3333}$ & 445,37 & - & - \\
\hline$D_{1212}$ & 132,14 & - & - \\
\hline$D_{1313}$ & 715 & - & - \\
\hline$D_{2323}$ & 715 & - & - \\
\hline
\end{tabular}

Reinforced concrete plate and rounded timber beams were modelled by using "solid" final $3 \mathrm{D}$ elements with 8 nodes, of type C3D8R. These elements in each node have 6 degrees of freedom, 3 displacements and 3 rotations. The analysis of mesh discretisation was carried out to determine compatible value of final elements in relation to material heterogeneity of model. More suitable mesh discretisation was adopted in the zone of contact of head screw, having in mind their cylindrical shape, with timber and concrete parts, as well as in support zones of beams, in order to obtain precisely the value of horizontal displacements between timber and concrete part of composite crosssection.

In the following figures (Figs. 7-11), some results of stress and strain analysis, obtained by numerical simulation in software ABAQUS 6.11, are presented.

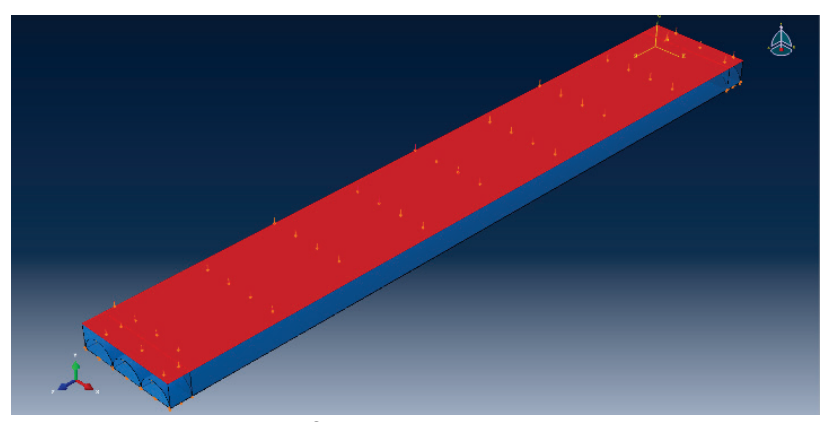

Figure 7 Static system, ultimate loading

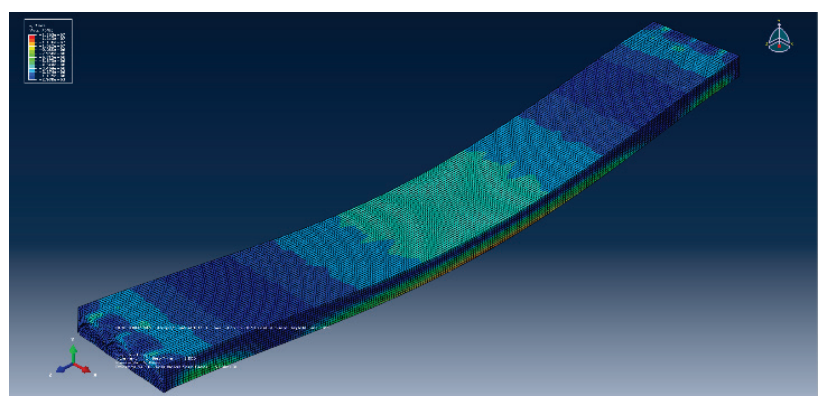

Figure 8 Stress distribution S11

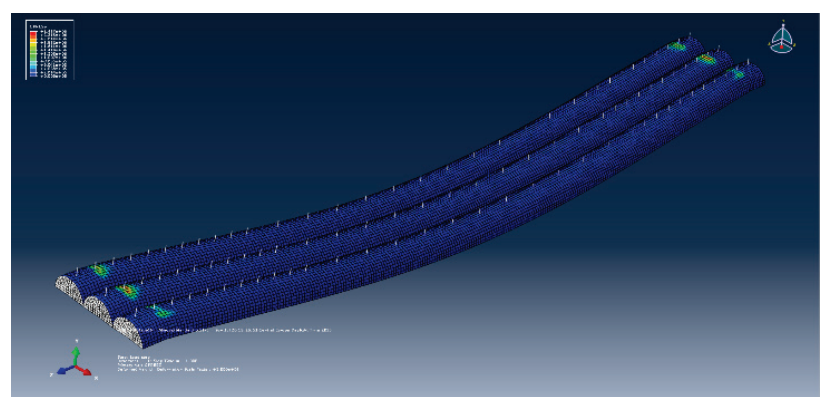

Figure 9 Shear stress in the connecting surface of concrete and timber part

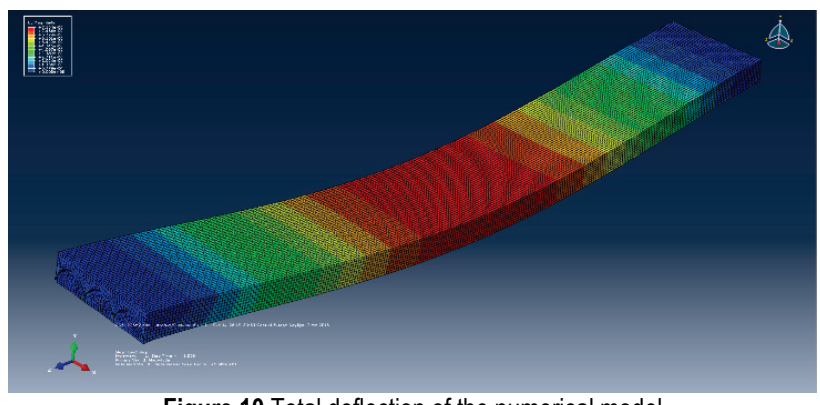

Figure 10 Total deflection of the numerical model 


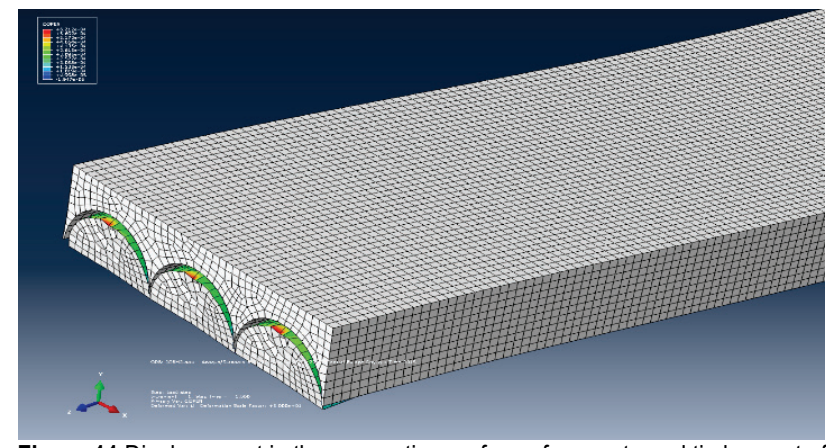

Figure 11 Displacement in the connecting surface of concrete and timber part of cross-section in support zone

The values of stress-deformation parameters determined by analytical process in EC 5 and numerical simulation, as well as their comparison, are shown in Tab. 9.

Table 9 Comparison of the results of theoretically-numerical analysis

\begin{tabular}{|c|c|c|}
\hline Condition & The values acc. to EC 5 & $\begin{array}{c}\text { The values given by } \\
\text { ABAQUS 6.11 }\end{array}$ \\
\hline$\sigma_{\mathrm{c}, \mathrm{d}}$ & $7,90 \mathrm{MPa}$ & $6,113 \mathrm{MPa}$ \\
\hline$\sigma_{\mathrm{c}, \mathrm{d}, \mathrm{d}}$ & $4,96 \mathrm{MPa}$ & $3,112 \mathrm{MPa}$ \\
\hline$\sigma_{\mathrm{m}, 2, \mathrm{~d}}$ & $3,12 \mathrm{MPa}$ & $2,916 \mathrm{MPa}$ \\
\hline$\tau_{2, \mathrm{max}}$ & $0,31 \mathrm{MPa}$ & $0,265 \mathrm{MPa}$ \\
\hline$u_{1, \mathrm{fin}}$ & $19,7 \mathrm{~mm}$ & $16,32 \mathrm{~mm}$ \\
\hline
\end{tabular}

\section{ERECTION}

After installing the head screws with adopted distance along the rounded timber beams, assembly of reinforcement mesh (Fig. 13 and 14), on the lower side of timber floor structure the scaffolds were set (Fig. 12). This structure of scaffolds supports timber floors on the half of span, with the adopted precamber, and has the function of accepting loading of fresh concrete mass [14].

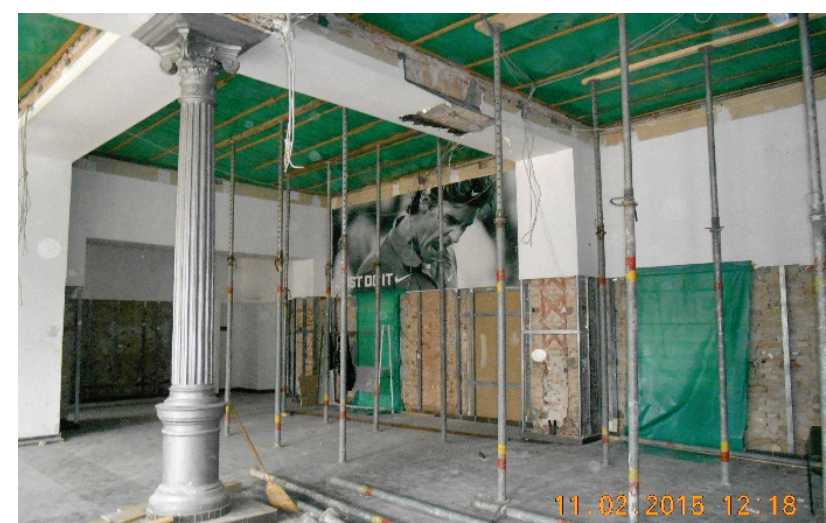

Figure 12 Scaffolding structure under timber floor

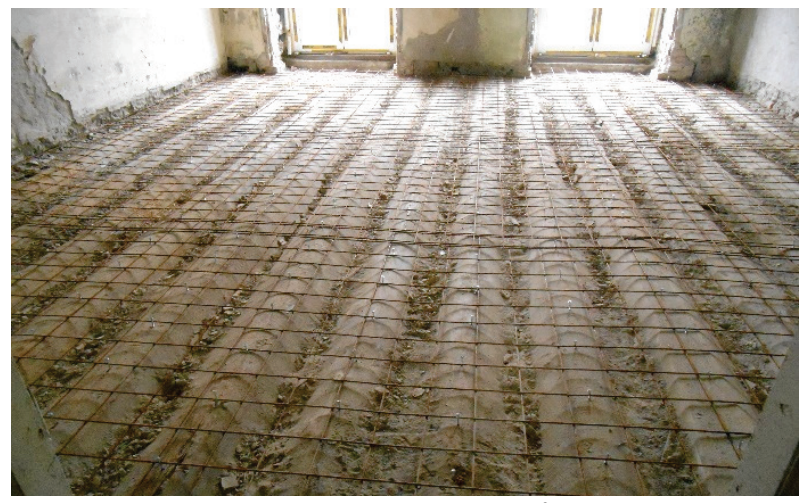

Figure 13 Rounded timber beams and reinforcement mesh
After such preparation only it is possible to apply concrete $\mathrm{C} 25 / 30$ and build it in according to concrete technology regulation (Fig. 15). The smallest thickness of concrete plate should be $d_{\mathrm{p}}=8 \mathrm{~cm}$, or due to geometry and shape of rounded timber elements, $d_{\mathrm{p}}=6 \mathrm{~cm}$.

In the webs ("pockets") between rounded timber beams and in volume of the concrete plate itself, a proper concrete should be built in, which consists of $40-50 \%$ of fraction $1,35-40 \%$ of fraction 2 and $10-15 \%$ of fraction 3 .

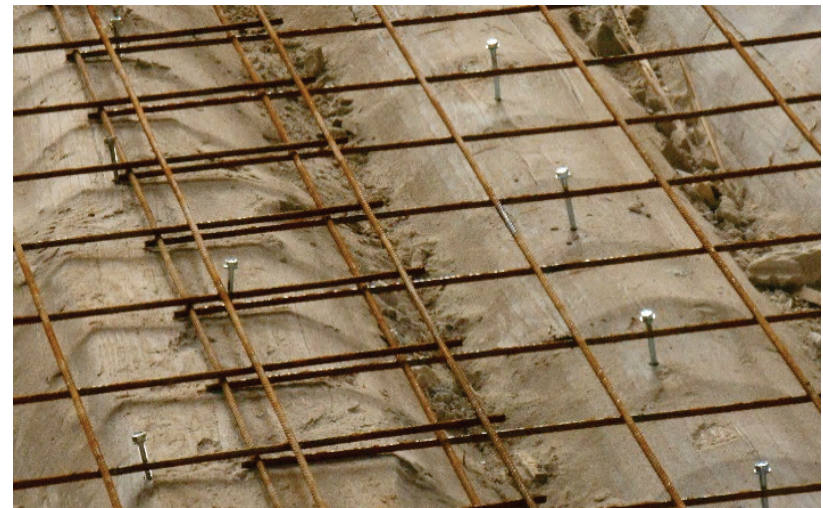

Figure 14 Connecting system head screw $d=10 \mathrm{~mm}$

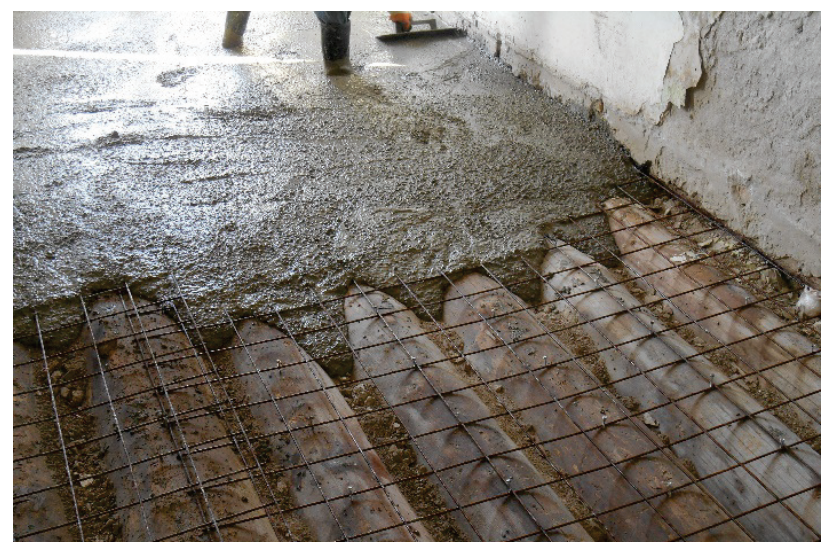

Figure 15 Erection of composite timber -concrete floor

\section{CONCLUSION}

The method of timber-concrete coupling by different connecting systems has been seen in the last few decades as a modern procedure used often, not only in repair and reconstruction of old, historical objects, but also in projecting new ones, especially bridges, timber floor structures of apartment and office blocks [15].

With estimated mechanical characteristics of these two materials, in the considered case of the Diocese in Pančevo, and by comparative analytical-numerical simulation of mechanical behaviour, in accordance with the hypotheses of theory of elastic coupling, a complete verification of this method was given. On the basis of the obtained results, the conditions were made for its practical appliance in repair and strengthening of old Diocese timber floors. By photos we have shown the construction procedures necessary for strengthening timber floor structures by technique of coupling timber with concrete. Comparative review of results obtained by analytical-numerical procedure, to a certain extent shown in this paper, with values of mechanical parameters which can be obtained by testing structure under certain loading conditions, will give the 
base for new conclusions about mechanical behaviour of composite timber-concrete floor structures. We have a plan to do such testing very soon.

Finally, we should say that objects of cultural and historical importance, as it is the object in this paper, from the point of preserving, strengthening and maintenance, deserve far more attention than we, as a community, give to them.

\section{REFERENCES}

[1] Ceccotti, A. (1995). Timber-concrete composite structures, Structural Timber Engineering Proceedings 2 (STEP 2), lecture E13.

[2] Grković, S., Kukaras, D., Santrač, P. Aladžić, V. \& Bajić, Ž. (2014). Reliability, condition diagnostics and reconstruction of the extremely damaged building. Tehnički vjesnik, 21(6), 1423-1432.

[3] Folić, R., Radonjanin, V., \& Malešev, M. (1999). Procena stanja građevinskih objekata-poglavlje: Pregled objekata i dijagnostika stanja konstrukcija građevinskih objekata, DDOR Novi Sad i Fakultet tehničkih nauka Univerziteta u Novom Sadu, Novi Sad. (in Serbian)

[4] ENV 1995-1-1. Eurocode 5: Design of timber structures, Part 1.1: General rules and rules for building. European Committee for Standardisation. 1993.

[5] ENV 1992-1-1. Eurocode 2: Design of concrete structures, Part 1.1: General rules and rules for building, European Committee for Standardisation 1993;

[6] Dias, A., Lopes, S., Van de Kuilen, J., \& Cruz, H. (2007). Load-carryingcapacity of timber-concrete joints with doweltype fasteners. Journal of Structural Engineering, 133(5), 720-727. https://doi.org/10.1061/(ASCE)0733-9445(2007)133:5(720)

[7] Blaß, H. J. \& Schlager, M. (1996). Trag-und Verformungsverhalten von Holz-Beton-Verbundkonstruktionen-Teil 1. Bauen mit Holz, 5/96, 392-399.

[8] Blaß, H. J., Van der Linden, M., \& Schlager, M. (1996) Tragund Verformungsverhalten von Holz-Beton-Verbundkonstruktionen-Teil 2. Bauen mit Holz, 6/96, 472-477.

[9] Cvetković, R. (2002). Behaviour of Composite TimberConcrete Structures with Bending Actions, Masters thesis, Department of Reinforced Concrete and Prestressed Concrete Structures, Ruhr University Bochum, Germany.

[10] Cvetković, R. \& Stojić, D. (2004). Design methods of a timber-concrete T-cross-section. Facta Universitatis, SeriesArchitecture and Civil Engineering, 2(4), University of Niš. https://doi.org/10.2298/FUACE0305329C

[11] Stevanović, B. (2003). Analysis of Composite TimberConcrete Structures, Doctoral thesis, Faculty of Civil Engineering, Belgrade.

[12] Stojić, D., Cvetković, R., Conić, S., \& Marković, N. (2015). Granično stanje upotrebljivosti drvenih međuspratnih konstrukcija. Savremena dostignuća u građevinarstvu, Subotica, 147-154, ISBN 978-86-80297-62-0. (in Serbian)

[13] Simulia. ABAQUS v.6.11 [Computer Software], Dassault Systems, 2012

[14] (2015). Glavni projekat rekonstrukcije i sanacije zgrade Biskupije u Pančevu. (in Serbian)

[15] Cvetković, R., Stojić, D., Conić, S., \& Marković, N. (2014). An Innovative Timber Structural Elements in Modern Construction. The $26^{\text {th }}$ Conference and International Symposium on Researching and Applying the Latest Developments in Civil Engineering in the Fields of Materials and Structures, Vrnjačka Banja, Srbija, 345-354, ISBN 978-8687615-05-2.

\section{Contact information:}

Radovan CVETKOVIĆ, PhD, assistant

Faculty of Civil Engineering and Architecture, University of Niš, Aleksandar Medvedev Street 14, 18000 Niš, Serbia

E-mail: radovan.cvetkovic@gaf.ni.ac.rs, radovancvetkovic@yahoo.com

Dragoslav STOJIĆ, PhD, full professor,

Faculty of Civil Engineering and Architecture, University of Niš, Aleksandar Medvedev Street 14, 18000 Niš, Serbia

E-mail: dragoslav.stojic@gmail.com

Nemanja MARKOVIĆ, dipl. ing., assistant

Faculty of Civil Engineering and Architecture, University of Niš, Aleksandar Medvedev Street 14, 18000 Niš, Serbia

Faculty of Civil and Environmental Engineering, Ruhr University Bochum, Universitatsstrasse 150, 44801 Bochum, Germany

E-mail: nemanja.markovic@gaf.ni.ac.rs

Marina TRAJKOVIĆ, PhD, assistant

Faculty of Civil Engineering and Architecture, University of Niš, Aleksandar Medvedev Street 14, 18000 Niš, Serbia

E-mail: marina.trajkovic@gaf.ni.ac.rs

Darko ŽlVKOVIĆ, PhD, assistant

Faculty of Civil Engineering and Architecture, University of Niš, Aleksandar Medvedev Street 14, 18000 Niš, Serbia

E-mail: darko.zivkovic@gaf.ni.ac.rs 